\title{
Kualitas Penerapan Asesmen Autentik Berbasis HOTS Guru Geografi SMA
}

\section{Ni Putu Desi Budiastini *1, Ida Bagus Made Astawa ${ }^{2}$, I Putu Sriartha ${ }^{3}$}

${ }^{1}$ Universitas Pendidikan Ganesha, Indonesia

2 Universitas Pendidikan Ganesha, Indonesia

${ }^{3}$ Universitas Pendidikan Ganesha, Indonesia

\author{
A R T I C L E I N F O \\ Article history: \\ Received 09 June 2020 \\ Received in revised form \\ 21 July 2020 \\ Accepted 27 July 2020 \\ Available online 31 August \\ 2020

\section{Kata Kunci:} \\ Asesmen Autentik; HOTS; \\ Konten; Kendala; Solusi \\ Keywords: \\ Authentic Assessment; \\ HOTS; Content; Constraints; \\ Solutions
}

\begin{abstract}
A B S T R A K
Penelitian ini bertujuan untuk menganalisis pemahaman Guru Geografi SMA terakreditasi A di Kota Singaraja tentang asesmen autentik berbasis HOTS, menganalisis kandungan HOTS pada asesmen autentik yang dikembangkan guru Geografi SMA terakreditasi A di Kota Singaraja, dan mengkaji kendala yang dihadapi Guru Geografi SMA terakreditasi A di Kota Singaraja dalam mengembangkan asesmen autentik berbasis HOTS. Penelitian ini merupakan studi populasi yang dilaksanakan di SMA terakreditasi A di Kota Singaraja. Objek penelitian: pemahaman guru terhadap asesmen autentik berbasis HOTS, kandungan HOTS dalam asesmen autentik yang dikembangkan, dan Kendala yang dihadapi dalam mengembangkan asesmen berbasis HOTS. Data dikumpulkan melalui metode observasi, wawancara, dan dokumentasi, selanjutnya dianalisis secara deskriptif kualitatif. Hasil penelitian menunjukkan pemahaman guru terkategori cukup. Soal-soal yang dibuat oleh guru belum sepenuhnya mengandung HOTS dan masih terkategori cukup. Kendala yang dihadapi guru dalam penerapan asesmen autentik berbasis HOTS bervariasi antar sekolah, kendala utama yang dihadapi adalah waktu dan siswa.
\end{abstract}

\section{A B S T R A C T}

This study aims to analyze the understanding of Geography Teachers accredited A high school in Singaraja City about HOTS-based authentic assessments, analyze the content of HOTS on authentic assessments developed by Geography teachers in SMA in Singaraja City, and assessing constraints faced by Geography Teachers from A accredited high school in Singaraja City in developing the HOTS-based assessment as a form of curriculum implementation in 2013. The Research is a population study conducted at A accredited high school in Singaraja City. The object of the research is focused on the teacher's understanding of the authentic HOTS-based assessment, the content of HOTS in the authentic assessment that was developed, and the obstacles encountered in developing the HOTS-based assessment. Data collected through observation methods. The results of the study showed that the understanding of categorized teachers was sufficient. The questions made by the teacher do not fully contain HOTS and are still categorized as sufficient. The obstacles faced by teachers in the application of HOTS-based authentic assessments vary between schools, the main constraints faced are time and students.

\footnotetext{
* Corresponding author.

E-mail addresses: desi.astini@gmail.com
} 


\section{Pendahuluan}

Kurikulum merupakan seperangkat rencana dan pengaturam mengenai tujuan, isi, dan bahan pelajaran serta cara yang digunakan sebagai pedoman penyelenggaraan kegiatan pembelajaran untuk mencapai tujuan pendidikan tertentu (Undang Undang Nomor 20 Tahun 2003 Tentang Sistem Pendidikan Nasional, 2003). Pendidikan di Indonesia saat ini menggunakan kurikulum 2013 Revisi. Berdasarkan Peraturan Menteri Pendidikan dan Kebudayaan Republik Indonesia Nomor 36 Tahun 2018 pada kurikulum 2013 revisi ada beberapa tuntutan yang menjadi tujuan, yaitu mempersiapkan manusia Indonesia agar memiliki kemampuan hidup sebagai pribadi dan warga negara yang beriman, produktif, kreatif, inovatif, dan afektif serta mampu berkontribusi pada kehidupan bermasyarakat, berbangsa, bernegara, dan peradaban dunia.

Kurikulum 2013 revisi menekankan pada kecerdasan siswa yang diimbangi oleh sikap ketuhanan dan nilai- nilai sosial yang terintegrasi dalam proses pembelajaran. Peserta didik harus dapat memberdayakan penalarannya. Kemampuan berpikir yang kritis dan komplek akan mampu menjadikan peserta didik terbiasa menghadapi persoalan yang sulit (Koswara, 2014). Untuk menghadapi persoalan yang sulit dan menciptakan pemikiran yang kritis peserta didik memerlukan kemampuan berpikir yang tinggi atau Higher Order Thinking Skill (HOTS) (Peraturan Menteri Pendidikan dan Kebudayaan Republik Indonesia Nomor 36 Tahun 2018 Tentang Perubahan Aatas Peraturan Menteri Pendidikan dan Kebudayaan Nomor 59 Tahun 2014 Tentang Kurikulum 2013 Sekolah Menengah Atas/Madrasah Aliyah, 2018). Berkenaan dengan itu pengembangan asesmen autentik berbasis HOTS sangat dibutuhkan dalam pembelajaran sesuai dengan tuntutan kurikulum 2013 revisi.

Selain itu, revolusi Industri 4.0 saat ini menjadi tren baru yang sedang berlangsung dan juga merupakan fenomena global. Banyak hal yang harus dipersiapkan dalam era Revolusi Industri 4.0 ini. Selain teknologi, yang juga sangat diperlukan dalam revolusi industri ini adalah SDM (Sumber Daya Manusia) berkualitas. Berkenaan dengan itu banyak perubahan dalam pembelajaran yang perlu dilaksanakan untuk menterjadikan Sumber daya manusia Indonesia yang berkualitas. Salah satunya ialah melalui mengimplementasikan karakter pembelajaran abad 21 dengan 4 C, yaitu : 1) Communication (Komunikasi), 2) Collaboration (Kerjasama), 3) Critical Thinking and Problem Solving (Berpikir Kritis dan Pemecahan Masalah), 4) Creativity and Innovation (Daya cipta dan Inovasi).

Perkembangan global yang terjadi di abad ke-21 dapat menjadikan proses pembelajaran hanya dalam bentuk pemerosesan informasi, namun harus dikembangkan sedemikian rupa sehingga mampu mengembangkan sumberdaya manusia kreatif yang adaptif terhadap tuntutan yang berkembang di dunia. Pembelajaran yang bermakna dan menantang tersebut penting dikembangkan dalam membentuk masyarakat pebelajar (Astawa, 2015).

Sejalan dengan itu HOTS sangat dibutuhkan tidak saja dalam memenuhi tuntutan kurikulum 2013 revisi tetapi juga dalam pembelajaran abad 21. Pengembangan dan penerapan HOTS dalam kegiatan belajar mengajar, peserta didik akan memiliki pemikiran yang lebih dalam dan kritis. Pengembangan HOTS dalam asesmen autentik yang dilakukan guru masih memiliki beberapa kendala. Pengembangan instrumen pembelajaran dan karakter, emosi, intelektual, perilaku, kecenderungan, serta kebiasaan peserta didik yang beragam merupakan sejumlah kendala yang dihadapi guru untuk pengembangan HOTS dalam asesmen autentiknya (Nurhayani, 2017). Kemampuan peserta didik yang tidak merata terutama pada kemampuan berpikir akan menyulitkan guru dalam menerapkan HOTS. Kemampuan berpikir Tinggi pada setiap peserta didik tidak dapat diratakan dan dipaksa begitu saja. Guru harus menyiasati hal tersebut dengan baik dan dapat merangsang nalar dan pemikiran peserta didik tersebut.

Pemahaman guru terhadap asesmen autentik yang mejadi tuntutan kurikulum 2013 edisi revisi juga dinilai rendah. Tidak semua guru memahami dengan baik bagaimana penerapan asesmen autentik atau apa saja komponen yang harus dipenuhi dalam asesmen autentik ini. Apabila asesmen autentik tidak dapat dipahami dengan baik, otomatis pengembangan HOTS dalam asesmen ini juga akan sulit. Untuk mengembangkan HOTS dalam asesmen autentik, guru terlebih dahulu harus mengerti dan paham dengan asesmen autentik. Hal ini diperkuat melalui penelitian yang sudah dilakukan sebelumnya seperti yang dilakukan oleh: Nurhayani (2017), Abdullah et al., (2017), Iskandar \& Senam (2015), Wahyuningtyas \& Ratnawati (2018), Fanani (2018), Shidiq, Masykuri, \& Susanti (2015), Zebua \& Harmalis (2019), Marhaeni \& Kusuma (2017).

Kota Singaraja memiliki empat (4) Sekolah Menengah Atas (SMA) terakreditasi A yang membelajarkan Geografi, yaitu SMA Negeri 1 Singaraja, SMA Negeri 2 Singaraja, SMA Negeri 3 Singaraja, dan SMA Negeri 4 Singaraja, dan SMA Laboratorium Undiksha. Kelima sekolah ini jaraknya relatif dekat dengan Undiksha sebagai Lembaga Pendidikan Tenaga Kependidikan (LPTK), sehingga komunikasi yang baik semestinya dapat terjalin mudah antara Guru Geografi dan Dosen Pendidikan Geografi di UNDIKSHA termasuk dalam pengembangan alat evaluasi yang berbasis HOTS. Berdasarkan hasil observasi awal yang dilakukan di salah satu SMA, memperlihatkan bahwa guru memang sudah mengembangkan asesmen berbasis HOTS pada alat evaluasi hasil belajar peserta didik, namun belum semua soal-soal yang dibuat merupakan soal yang berbentuk HOTS. Soal- 
soal yang dikembangkan hanya beberapa yang sudah mengandung dimensi kognitif C4, C5, C6. Sebagian besar soal yang dikembangkan masih berada pada didimensi kognitif C2 dan C3. Hal ini menunjukan bahwa alat-alat/ instrumen asesmen pembelajaran yang dikembangkan guru belum mengacu asesmen autentik yang berbasis HOTS. Berdasarkan permasalahan tersebut dilakukan penelitian untuk mengkaji lebih lanjut tentang kandungan HOTS dalam asesmen autentik yang dikembangkan oleh guru-guru Geografi SMA terakreditasi A di kota Singaraja.

Penelitian serupa yang pernah diteliti sebelumnya adalah penelitian dari (Nurhayani, 2017) dengan judul Kesulitan Guru Dalam Pengembangan Keterampilan Berpikir Tingkat Tinggi Siswa Pada Pembelajaran Biologi Kelas XII Di SMA Negeri 2 Gowa. Penelitian dari Nurhayani 2017 dilaksanakan di SMA terakreditasi B. Perbedaan penelitian ini dengan penelitian lain yang telah dilakukan terkait dengan HOTS yang dikembangkan peneliti adalah pada lokasi penelitian yang dilaksanakan di SMA terakreditasi A di Kota Singaraja. Dilihat dari objek penelitian adalah pada kandungan HOTS yang terdapat dalam asesmen autentik yang dikembangkan oleh Guru Geografi. Sementara subjek penelitian adalah Guru-Guru Geografi SMA terakreditasi A. Fokus permasalahan pada penelitian ini meliputi Pemahaman guru-guru SMA Negeri di Kota Singaraja tentang asesmen autentik berbasis HOTS, kandungan HOTS dalam asesmen autentik yang dikembangkan Guru-Guru Geografi SMA terakreditasi A di Kota Singaraja, dan Kendala-kendala yang dihadapi guru dalam mengembangkan HOTS. Pengumpulan data dilakukan dengan cara observasi, wawancara, pencatatan dokumen dan dokumentasi, yang selanjutnya akan dianalisis secara deskriptif kualitatif. Penelitian sebelumnya yang sejenis seperti penelitian (Nurhayani, 2017) dan (Marhaeni \& Kusuma, 2017) yang dilaksanakan di SMA yang tidak terakreditasi A, (Abdullah et al., 2017) yang hanya fokus meneliti pada level pengetahuan berbeda dengan penelitian ini yang dilaksanakan di SMA terakreditasi A dan sudah mulai meneliti bukan hanya pada pemahaman/pengetahuan guru namun sampai diranah kandungan HOTS pada soal-soal yang telah dibuat sehingga selain pengetahuan, kemampuan guru dalam menerapkan asesmen autentik berbasis HOTS dapat dilihat melalui kandungan HOTS pada soal yang telah dibuat.

\section{Metode}

Penelitian ini dirancang sebagai penelitian deskriptif, karena gejala yang diteliti sudah ada secara wajar, berisi kutipan-kutipan data (fakta) dan tidak dibuat oleh peneliti (Anggito \& Setiawan, 2018). Pendeskripsian dilakukan terhadap: 1) pemahaman Guru-Guru Geografi SMA terakreditasi A di Kota Singaraja tentang asesmen autentik berbasis HOTS, 2) kandungan HOTS dalam asesmen autentik yang dikembangkan Guru-Guru Geografi SMA akreditasi A di Kota Singaraja, dan 3) kendala-kendala yang dihadapi guru dalam mengembangkan asesmen autentik berbasis HOTS sebagai pengimplementasian Kurikulum 2013. Penelitian dilakukan di Kota Singaraja, Kabupaten Buleleng, tepatnya pada SMA Negeri yang terakriditasi A, yaitu: SMA Negeri 1 Singaraja, SMA Negeri 2 Singaraja, SMA Negeri 3 Singaraja, SMA Negeri 4 Singaraja, dan SMA Laboratorium Undiksha. Penelitian ini menggunakan studi populasi yang mencakup semua guru geografi pada SMA terakreditasi A di kota Singaraja yang berjumlah lima (5) orang.

Data dikumpulkan menggunakan metode observasi, wawancara dan dokumentasi. Instrumen yang digunakan dalam penelitian ini berupa lembar tes evaluasi pemahaman guru untuk mengungkap pemahaman guru- guru terhadap asesmen autentik berbasis HOTS, instrumen telaah soal HOTS untuk mengetahui kandungan soal- soal yang telah dibuat oleh guru, dan pedoman wawancara terbuka untuk memperoleh informasi mengenai kendala yang dihadapi guru dalam penerapan asesmen autentik berbabis HOTS.

Terdapat tiga permasalahan yang memerlukan jawaban melalui data yang dikumpulkan. Pada teknik analisis deskriptif kualitiatif, peneliti akan menggambarkan/mendeskripsikan apa yang dikatakan subjek, proses yang berlangsung dan berbaai aktifitas lain dalam konteks alamiah (Helaluddin \& Wijaya, 2019). Data untuk menjawab permasalahan 1 dan 2 dianalisis secara deskriptif kualitatif melalui teknik analisis tabel. Data yang sudah diolah ditampilkan dalam bentuk tabel sesuai dengan indikator yang digunakan dalam pengukurannya. Melalui analisis tabel tersebut dapat dibandingkan secara kualitatif antara sekolah satu dengan lainnya. Sementara data untuk menjawab permasalahan 3 juga dianalisis secara deskriptif kualtatif. Kendala-kendala yang dikemukakan oleh masing-masing guru deskripsikan secara kualitatif sehingga dapat digambarkan persamaan dan perbedaannya antara guru di sekolah yang satu dengan guru di sekolah yang lainnya.

\section{Hasil dan pembahasan}

\section{Pemahaman Guru SMA Terakriditasi A di Kota Singaraja terhadap Asesmen Autentik Berbasis HOTS}

Terdapat empat indikator yang digunakan dalam tes untuk mengukur pemahaman Guru SMA Terakriditasi A di Kota Singaraja terhadap Asesmen Autentik Berbasis HOTS, yaitu: (1) pemahaman tentang Konsep Asesmen Autentik berbasis HOTS, (2) Pemahaman tentang Ciri-Ciri dan Karakteristik asesmen autentik 
berbasis HOTS, (3) Pemahaman tentang langkah menyusun soal berbasis HOTS, dan (4) Pemahaman tentang cara menilai siswa dengan asesmen autentik berbasis HOTS. Hasil penelitian yang dilakukan menunjukkan bahwa pemahaman guru geografi SMA terakriditasi A di Kota Singaraja terhadap asesmen autentik berbasis HOTS terkategori sedang dengan skor rata-rata 83. Skor tertinggi untuk pemahaman terhadap Asesmen autentik berbasis HOTS adalah 100, sementara yang terendah 70 . Jika dilihat antar indikator dan antar sekolah terlihat ada variasi. Untuk jelasnya perhatikan Tabel 1.

Tabel 1.

Skor Pemahaman Guru Geografi SMA di Kota Singaraja

\begin{tabular}{|c|c|c|c|c|c|c|c|}
\hline \multirow[t]{2}{*}{ No } & \multirow[t]{2}{*}{ Indikator } & \multicolumn{6}{|c|}{ Skor pada SMA } \\
\hline & & $\begin{array}{c}\text { Sekolah } \\
1 \\
\end{array}$ & $\begin{array}{c}\text { Sekolah } \\
2 \\
\end{array}$ & $\begin{array}{c}\text { Sekolah } \\
3 \\
\end{array}$ & $\begin{array}{c}\text { Sekolah } \\
4 \\
\end{array}$ & $\begin{array}{c}\text { Sekolah } \\
5\end{array}$ & Rerata \\
\hline 1 & $\begin{array}{l}\text { Pemahaman tentang } \\
\text { Konsep Asesmen Autentik } \\
\text { berbasis HOTS }\end{array}$ & 15 & 15 & 25 & 20 & 25 & 20 \\
\hline 2 & $\begin{array}{l}\text { Pemahaman tentang ciri- } \\
\text { ciri dan karakteristik } \\
\text { asesmen autentik berbasis } \\
\text { HOTS }\end{array}$ & 20 & 25 & 25 & 15 & 25 & 24 \\
\hline 3 & $\begin{array}{l}\text { Pemahaman tentang } \\
\text { langkah menyusun soal } \\
\text { berbasis HOTS }\end{array}$ & 20 & 25 & 25 & 25 & 25 & 24 \\
\hline \multirow[t]{2}{*}{4} & $\begin{array}{l}\text { Pemahaman tentang cra } \\
\text { menilai siswa dengan } \\
\text { asesmen autentik berbasis } \\
\text { HOTS }\end{array}$ & 25 & 15 & 15 & 10 & 25 & 18 \\
\hline & $\begin{array}{ll} & \text { Total } \\
\end{array}$ & 80 & 80 & 85 & 70 & 100 & 83 \\
\hline
\end{tabular}

Sumber: Data primer

Keterangan: Skor 90-100 (Sangat Paham/Tinggi), 50-89 (Cukup Paham/Sedang), <50\% (Tidak Paham/Rendah)

Tabel 1 menunjukkan bahwa dilihat dari indikator yang digunakan mengukur pemahaman guru terhadap asesmen autentik, skor tertinggi terlihat pada pemahaman tentang Ciri-Ciri dan Karakteristik asesmen autentik berbasis HOTS dan pemahaman tentang langkah menyusun soal berbasis HOTS. Sementara yang terendah adalah pemahaman tentang cara menilai siswa dengan asesmen autentik berbasis HOTS. Tidak ada pola skor yang terlihat jelas antar indikator yang digunakan. Skor tertinggi maupun skor terendah dimasing-masing sekolah tidak hanya terdapat di 1 indikator saja. Sekolah 1 skor tertinggi terdapat pada indikator 4 dan terendah di indikator 1. Sekolah 2 skor tertinggi terdapat pada indikator 2 dan 3, sedangkan skor terendar terdapat pada indikator 1 dan 4 . Sekolah 3 skor tertinggi terdapat pada indikator 1,2,3 sedangkan skor terendah terdapat pada indikator 4 . Sekolah 4 skor tertinggi terdapat pada indikator 3 dan terendah terdapat pada indikator 4 . Sekolah 5 mendapat seluruh nilai tinggi pada keempat indikator. Sehingga dapat diketahui bahwa tidak ada pola yang jelas/beraturan antar skor pada masing-masing indikator. Jika dilihat antar sekolah, hanya satu guru yang yang berhasil memperoleh skor tinggi, sehingga pemahamannya terkategori baik (90 100). Guru sekolah ini mampu memperoleh skor yang sempurna yaitu 100. Sekolah lainnya masih memiliki skor dibawah 90 sehingga belum dapat dikategorikan pemahaman tinggi. Sekolah 1 memiliki skor 80, sekolah 2 memiliki skor 80, sekolah 3 memiliki skor 85, dan sekolah 4 memiliki skor terendah diantara 5 sekolah yang diteliti yaitu 70 .

\section{Kandungan HOTS dalam Asesmen Autentik yang dikembangkan Guru SMA Terakriditasi A di Kota Singaraja}

Pengukuran kandungan HOTS dalam asesmen autentik yang dikembangkan Guru Geografi SMA Terakriditasi A di Kota Singaraja menggunakan empat (4) aspek yang dinilai pada tiap butir soalnya, yaitu: (1) Soal menggunakan stimulus yang menarik (baru, mendorong peserta didik untuk membaca), (2) Soal menggunakan stimulus yang kontekstual (gambar/grafik, teks, visualisasi, dll, sesuai dengan dunia nyata), (3) Soal mengukur level kognitif penalaran (menganalisis, mengevaluasi, mencipta) yang dalam penyelesaiannya dicirikan dengan salah satu atau lebih tahapan proses berpikir, dan (4) Jawaban tersirat pada stimulus. Hasil pengukuran menunjukkan bahwa kandungan HOTS dalam soal-soal yang disusun Guru Geografi SMA di Kota Singaraja rata-rata hanya $46,27 \%$ terkategori sedang. Hal tersebut secara konsisten terlihat pada semua sekolah maupun antar jenjang kelas dan bentuk soal. Untuk jelasnya dapat dilihat pada Tabel 2. 
Tabel 2.

Persentase Kandungan HOTS pada Soal-soal yang dikembangkan Guru-guru SMA Terakriditasi A di Kota Singaraja

\begin{tabular}{|c|c|c|c|c|c|c|c|}
\hline \multirow[t]{2}{*}{ Kelas } & \multirow[t]{2}{*}{ Bentuk Soal } & \multirow[t]{2}{*}{ Aspek } & \multicolumn{5}{|c|}{ Soal yang Memenuhi Syarat HOTS (\%) } \\
\hline & & & Sekolah 1 & Sekolah 2 & Sekolah 3 & Sekolah 4 & Sekolah 5 \\
\hline \multirow{4}{*}{$x$} & \multirow{4}{*}{ Objektif } & 1 & $47,5 \%$ & $27,5 \%$ & - & $15 \%$ & $35 \%$ \\
\hline & & 2 & $45 \%$ & $45 \%$ & - & $42,5 \%$ & $47,5 \%$ \\
\hline & & 3 & $17,5 \%$ & $50 \%$ & - & $32,5 \%$ & $30 \%$ \\
\hline & & 4 & $37,5 \%$ & $55 \%$ & - & $55 \%$ & $67,5 \%$ \\
\hline \multicolumn{3}{|c|}{ Rata-rata Total Kelas X } & $36,68 \%$ & $44,37 \%$ & - & $36,25 \%$ & $45 \%$ \\
\hline \multirow{4}{*}{$\mathrm{XI}$} & \multirow{4}{*}{ Objektif } & 1 & $17,5 \%$ & $30 \%$ & $25 \%$ & $2,5 \%$ & $17,5 \%$ \\
\hline & & 2 & $67,5 \%$ & $55 \%$ & $40 \%$ & $50 \%$ & $50 \%$ \\
\hline & & 3 & $27,5 \%$ & $57,5 \%$ & $32,5 \%$ & $20 \%$ & $10 \%$ \\
\hline & & 4 & $47,5 \%$ & $37,5 \%$ & $57,5 \%$ & $80 \%$ & $55 \%$ \\
\hline \multicolumn{3}{|c|}{ Rata-rata Total Kelas XI } & $40 \%$ & $45 \%$ & $38,75 \%$ & $38,12 \%$ & $33,12 \%$ \\
\hline \multirow{4}{*}{ XII } & \multirow{4}{*}{ Objektif } & 1 & $15 \%$ & $20 \%$ & $22,5 \%$ & $22,5 \%$ & $70 \%$ \\
\hline & & 2 & $52,5 \%$ & $36 \%$ & $32,5 \%$ & $40 \%$ & $70 \%$ \\
\hline & & 3 & $27,5 \%$ & $68 \%$ & $27,5 \%$ & $37,5 \%$ & $47,5 \%$ \\
\hline & & 4 & $62,5 \%$ & $44 \%$ & $52,5 \%$ & $70 \%$ & $67,5 \%$ \\
\hline \multicolumn{3}{|c|}{ Rata-rata Total Kelas XII } & $36,37 \%$ & $42 \%$ & $33,75 \%$ & $42,5 \%$ & $63,75 \%$ \\
\hline \multirow{4}{*}{$x$} & \multirow{4}{*}{ Uraian } & 1 & & - & - & $0 \%$ & $40 \%$ \\
\hline & & 2 & & - & - & $60 \%$ & $40 \%$ \\
\hline & & 3 & & - & - & $60 \%$ & $40 \%$ \\
\hline & & 4 & & - & - & $80 \%$ & $40 \%$ \\
\hline \multicolumn{3}{|c|}{ Rata-rata Total Kelas X } & & - & - & $50 \%$ & $40 \%$ \\
\hline \multirow{4}{*}{$X I$} & \multirow{4}{*}{ Uraian } & 1 & & $0 \%$ & $25 \%$ & $0 \%$ & $20 \%$ \\
\hline & & 2 & & $100 \%$ & $40 \%$ & $80 \%$ & $20 \%$ \\
\hline & & 3 & & 0 & $32,5 \%$ & $60 \%$ & $60 \%$ \\
\hline & & 4 & & $100 \%$ & $57,5 \%$ & $80 \%$ & $60 \%$ \\
\hline \multicolumn{3}{|c|}{ Rata-rata Total Kelas XI } & & $50 \%$ & $70 \%$ & $55 \%$ & $40 \%$ \\
\hline \multirow{4}{*}{ XII } & \multirow{4}{*}{ Uraian } & 1 & & $0 \%$ & $22,5 \%$ & $60 \%$ & $0 \%$ \\
\hline & & 2 & & $40 \%$ & $32,5 \%$ & $80 \%$ & $100 \%$ \\
\hline & & 3 & & $0 \%$ & $27,5 \%$ & $60 \%$ & $60 \%$ \\
\hline & & 4 & & $100 \%$ & $52,5 \%$ & $80 \%$ & $100 \%$ \\
\hline \multicolumn{3}{|c|}{ Rata-rata Total Kelas XII } & & $35 \%$ & $80 \%$ & $70 \%$ & $65 \%$ \\
\hline \multicolumn{3}{|c|}{ Rata-rata Total Seluruh Kelas } & $38,68 \%$ & $43,27 \%$ & $52,96 \%$ & $48,64 \%$ & $47,81 \%$ \\
\hline
\end{tabular}

Sumber: Data primer

Keterangan: Persentase 80-100\% (tinggi), 50-79\% (Sedang), $<50 \%$ (Rendah)

Tabel 2 menunjukan bahwa secara umum kandungan HOTS pada soal-soal geografi yang sudah dibuat guru- guru Geografi SMA terakreditasi A di kota Singaraja terkategori sedang. Namun demikian, terdapat variasi antar sekolah maupun antar aspek. Jika dilihat antar aspek terlihat variasi pola yang terbentuk relatif ajeg. Rata-rata persentase tertinggi terdapat pada aspek empat (4) dan yang terendah pada aspek satu (1). jika memperhatikan antar sekolah, persentase kandungan HOTS-nya yang tertinggi terdapat di Sekolah ke-3 dengan persentase 52,96\%, sedangkan sekolah lainnya memperoleh persentase dibawah 50\%. Guru yang memiliki pemahaman terhadap Asesmen Autentik berbasis HOTS yang terkategori tinggi disatu sekolah, namun kandungan HOTS pada soal-soal yang dikembangkan justru terdapat di sekolah lain. Terdapat dua sekolah yang persentase kandungan HOTS-nya di bawah nilai rata-rata total $(46,27 \%$, yaitu $(38,68 \%)$ dan $(43,27 \%)$.

Dilihat dari rata-rata kelas, terdapat variasi antar masing-masing sekolah. Pada kelas 10 dengan bentuk soal objektif rata-rata total tiap sekolah berkisar antara 36-45\%, sekolah dengan rata-rata tertinggi pada jenjang dan jenis soal ini tidak terlalu jauh dengan sekolah dengan rata-rata terendah pada jenjang dan jenis soal ini yaitu 45\% tertinggi pada Sekolah ke- 5 dan 36,25\% pada Sekolah ke-4. Pada kelas 11 dengan bentuk soal objektif rata-rata toal tiap sekolah berkisar antara 33-45\%, sekolah dengan rata-rata tertinggi pada jenjang dan jenis soal ini tidak terlalu jauh dengan sekolah dengan rata-rata terendah pada jenjang dan jenis soal ini yaitu $45 \%$ 
tertinggi pada Sekolah ke-2 dan 33,12\% pada Sekolah ke-5. Pada kelas 12 dengan bentuk soal objektif rata-rata toal tiap sekolah berkisar antara 33-63,75\%, sekolah dengan rata-rata tertinggi pada jenjang dan jenis soal ini cukup jauh dengan sekolah dengan rata-rata terendah pada jenjang dan jenis soal ini yaitu $63,75 \%$ tertinggi pada Sekolah ke-5 dan 33,75\% pada Sekolah ke-3.

Pada kelas 10 dengan bentuk soal uraian rata-rata toal tiap sekolah berkisar antara 40-50\%, sekolah dengan rata-rata tertinggi pada jenjang dan jenis soal ini tidak terlalu jauh dengan sekolah dengan rata-rata terendah pada jenjang dan jenis soal ini yaitu $50 \%$ tertinggi pada Sekolah ke-4 dan $40 \%$ pada Seolah ke-5. Pada kelas 11 dengan bentuk soal uraian rata-rata toal tiap sekolah berkisar antara $40-70 \%$, sekolah dengan rata-rata tertinggi pada jenjang dan jenis soal ini cukup jauh dengan sekolah dengan rata-rata terendah pada jenjang dan jenis soal ini yaitu 70\% tertinggi pada Sekolah ke-3 dan 40\% pada Sekolah ke -5. Pada kelas 12 dengan bentuk soal uraian rata-rata toal tiap sekolah berkisar antara $35-80 \%$, sekolah dengan rata-rata tertinggi pada jenjang dan jenis soal ini cukup jauh dengan sekolah dengan rata-rata terendah pada jenjang dan jenis soal ini yaitu $80 \%$ tertinggi pada Sekolah ke-3 dan 35\% pada Sekolah ke-2.

\section{Kendala Guru SMA Terakriditasi A di Kota Singaraja Guru dalam menyusunan Soal-soal Asesmen Autentik Berbasis HOTS}

Terdapat empat (4) indikator yang digunakan untuk menganalisis kendala-kendala Guru Geografi SMA Terakriditasi A di Kota Singaraja dalam penerapan asesmen autentik berbasis HOTS, yaitu: (1)Kendala-kendala pada saat penyusunan, (2) Kendala-kendala saat penerapan, (3) Kendala-kendala saat evaluasi/penilaian, dan (4) Solusi dan kiat dalam menghadapi kendala-kendala. Hasil penelitian dapat dikemukakan sebagaimana terlihat pada Tabel 3, 4, dan 5.

Tabel 3.

Kendala-kendala Guru Geografi SMA Terakriditasi A di Kota Singaraja dalam Penyusunan Soal-soal Asesmen Autentik Berbasis HOTS

\begin{tabular}{|c|c|c|c|c|}
\hline No & Sekolah & Kendala & Coding & $\begin{array}{l}\text { Line by } \\
\text { Line } \\
\text { Coding }\end{array}$ \\
\hline 1 & Sekolah 1 & $\begin{array}{l}\text { Waktu dan pemikiran harus disiapkan dengan } \\
\text { matang sehingga dalam penyusunan soal } \\
\text { memerlukan waktu yang lama }\end{array}$ & 1. Waktu & \multirow{5}{*}{$\begin{array}{l}\text { 1. Waktu } \\
\text { 2. Siswa } \\
\text { 3. KD } \\
\text { 4. Refrensi } \\
\text { 5. Memilih } \\
\text { Kata } \\
\text { Operasion } \\
\text { al } \\
\text { 6. } \\
\text { Menyusun } \\
\text { Soal }\end{array}$} \\
\hline 2 & Sekolah 2 & $\begin{array}{l}\text { Waktu dan kurang refrensi, sulit } \\
\text { membedakan soal, kemampuan kognitif siswa } \\
\text { yang tidak sama }\end{array}$ & $\begin{array}{l}\text { 1. Waktu } \\
\text { 2. Refrensi } \\
\text { 3. Siswa }\end{array}$ & \\
\hline 3 & Sekolah 3 & $\begin{array}{l}\text { Saat menganalisis KI dan KD, Saat menyusun } \\
\text { indikator pencapaian kompetensi, dan saat } \\
\text { memilih kata-kata operasional yang tepat }\end{array}$ & $\begin{array}{l}\text { 1. KD } \\
\text { 2. Menyusun } \\
\text { indikator } \\
\text { pencapaian } \\
\text { 3. Memilih kata } \\
\text { operasional }\end{array}$ & \\
\hline 4 & Sekolah 4 & $\begin{array}{l}\text { Pemilihan KD kadang kurang tepat, Pemilihan } \\
\text { soal harus memenuhi standar HOTS, dan } \\
\text { Membutuhkan waktu dan pemikiran yang } \\
\text { cukup lama }\end{array}$ & $\begin{array}{l}\text { 1. KD } \\
\text { 2. Waktu }\end{array}$ & \\
\hline 5 & Sekolah 5 & $\begin{array}{l}\text { Guru SMA Laboratorium Undikhsa } \\
\text { menyatakan hal ini bukan sebuah kendala } \\
\text { tetapi lebih ke tantangan yang dihadapi, yaitu } \\
\text { bagaimana menyusun soal-soal asesmen } \\
\text { autentik berbasis HOTS yang mampu } \\
\text { membuat siswa berpikir tingkat tinggi (kritis) } \\
\text { untuk memecahkan permasalahan } \\
\text { kontenstual yang mudah dipahami siswa } \\
\text { (melihat karakteristik siswa juga). }\end{array}$ & $\begin{array}{l}\text { 1. Menyusun } \\
\text { soal } \\
\text { 2. Siswa }\end{array}$ & \\
\hline
\end{tabular}

Sumber: Pengolahan data primer 
Tabel 3 menunjukkan ada variasi kendala yang dialami Guru Geografi SMA terakriditasi A di Kota Singaraja dalam penyusunan soal-soal asesmen autentik berbasis HOTS. Jika didentifikasi kendala yang dihadapi dalam penusunan soal-soal asesmen autentik berbsais HOTS tidak saja berkaitan dengan waktu, tetapi juga berkenaan dengan referensi yang digunakan sebagai rujukan, pertimbangan kemampuan siswa, penetapkan indikator pencapaian KD, dan menggunakan kata-kata operasional yang tepat.

Tabel 4.

Kendala-kendala Guru Geografi SMA Terakriditasi A di Kota Singaraja pada saat penerapan soal-soal asesmen autentik berbasis HOTS

\begin{tabular}{|c|c|c|c|c|}
\hline No & Sekolah & Kendala & Coding & $\begin{array}{l}\text { Line by } \\
\text { Line } \\
\text { Coding }\end{array}$ \\
\hline 1 & Sekolah 1 & $\begin{array}{l}\text { Dalam penerapannya sementara belum ada } \\
\text { kendala yang dihadapi }\end{array}$ & - & \multirow[t]{5}{*}{ 1. Siswa } \\
\hline 2 & Sekolah 2 & $\begin{array}{l}\text { Kemampuan kognitif pada setiap siswa yang } \\
\text { berbeda-beda }\end{array}$ & 1. Siswa & \\
\hline 3 & Sekolah 3 & $\begin{array}{l}\text { Respon peserta didik kurang (kecil). } \\
\text { Sebagian besar peserta didik tidak mau } \\
\text { berupaya untuk menjawab dengan } \\
\text { maksimal, dan minimnya kesiapan peserta } \\
\text { didik dalam menghadapi penilaian asesmen } \\
\text { autentik berbais HOTS. }\end{array}$ & 1. Siswa & \\
\hline 4 & Sekolah 4 & $\begin{array}{l}\text { Kurang referensi siswa terhadap teori yang } \\
\text { berkenaan dengan masalah yang dipelajari, } \\
\text { dan sulit membedakan jawaban pada soal } \\
\text { pilihan ganda, karena } \\
\text { jawaban yang tersedia sangat mirip }\end{array}$ & 1. Siswa & \\
\hline 5 & Sekolah 5 & $\begin{array}{l}\text { Untuk soal asesmen autentik berbasis HOTS } \\
\text { yang diberikan kepada siswa saat saat tes } \\
\text { (penilaian) berlangsung kurang dipahami } \\
\text { siswa, biasanya mereka akan bertanya. } \\
\text { Disinilah peran guru, mengarahkan maksud } \\
\text { dari soal asesmen autentik berbasis HOTS } \\
\text { tersebut }\end{array}$ & 1. Siswa & \\
\hline
\end{tabular}

Sumber: Pengolahan data primer

Tabel 4 menunjukkan bahwa kendala-kendala guru geografi SMA terakriditasi A di kota Singaraja pada saat penerapan soal-soal asesmen autentik berbasis HOTS sebagian besar adalah siswa/peserta didik yaitu pada motivasi peserta didik yang rendah dalam menjawab soal, perbedaan kemampuan peserta didik, dan kurangnya referensi yang dapat dibaca dalam memperluas wawasan peserta didik, sehingga dapat melatih diri untuk menjawab soal-soal yang berbasis HOTS.

Tabel 5.

Kendala-kendala Guru Geografi SMA Terakriditasi A di Kota Singaraja pada saat evaluasi dan penilaian siswa

\begin{tabular}{|l|l|l|l|l|}
\hline No & Sekolah & \multicolumn{1}{c|}{ Kendala } & \multicolumn{1}{c|}{ Coding } & \multicolumn{1}{c|}{$\begin{array}{c}\text { Line by Line } \\
\text { Coding }\end{array}$} \\
\hline 1 & Sekolah 1 & $\begin{array}{l}\text { Kendalanya adalah } \\
\text { Sikap : karena anak-anak berkelompok, } \\
\text { mereka terkadang mengobrol pada saat } \\
\text { kegiatan belajar mengajar, }\end{array}$ & $\begin{array}{l}\text { 1. Siswa } \\
\text { 2. Waktu } \\
\text { 3. Bentuk Soal }\end{array}$ & $\begin{array}{l}\text { 1. Waktu } \\
\text { 2. Siswa } \\
\text { 3. Bentuk Soal } \\
\end{array}$ \\
& $\begin{array}{l}\text { Keterampilan : Pada saat pengumpulan } \\
\text { tugas ada beberapa anak yang tidak } \\
\text { tepat waktu }\end{array}$ & & \\
\hline
\end{tabular}




\begin{tabular}{|c|c|c|c|}
\hline & & $\begin{array}{l}\text { Pengetahuan: soal dengan bentuk } \\
\text { pilihan ganda akan membuat } \\
\text { kesempatan bagi anak untuk } \\
\text { bekerja sama }\end{array}$ & \\
\hline 2 & Sekolah 2 & $\begin{array}{l}\text { Waktu belajar efektif yang singkat } \\
\text { sehingga terkadang saat evaluasi } \\
\text { kekurangan } \\
\text { Waktu }\end{array}$ & 1. Waktu \\
\hline 3 & Sekolah 3 & $\begin{array}{l}\text { Hasil evaluasi siswa yang relatif rendah } \\
\text { atau belum sesuai dengan harapan }\end{array}$ & 1. Siswa \\
\hline 4 & Sekolah 4 & $\begin{array}{l}\text { Evaluasi: Biasanya HOTS digunakan pada } \\
\text { uraian dengan jumlah soal sedikit tapi } \\
\text { waktu lama } \\
\text { Penilaian: Karena soal penalaran tadi } \\
\text { argumen yang dikeluarkan berbeda } \\
\text { setiap siswa. }\end{array}$ & $\begin{array}{l}\text { 1. Waktu } \\
\text { 2. Siswa }\end{array}$ \\
\hline 5 & Sekolah 5 & $\begin{array}{l}\text { Tidak ada, karena pada saat evaluasi dan } \\
\text { penilaian siswa disesuaikan dengan } \\
\text { rubrik penskoran dan kunci jawaban } \\
\text { yang telah dibuat/disusun. }\end{array}$ & - \\
\hline
\end{tabular}

Sumber: Pengolahan data primer

Tabel 5 menunjukkan kendala-kendala Guru Geografi SMA Terakriditasi A di Kota Singaraja pada saat evaluasi dan penilaian siswa. Soal-soal pilihan ganda memberikan peluang kerjasama antar siswa. Selain itu, kendala waktu dan hasil belajar yang rendah masih dijumpai pada evaluasi yang dilakukan. Pada soal penalaran dijumpai adanya keberagaman argument yang diberikan siswa pada soal yang sama.

Tabel 6.

Solusi dan Kiat yang Pernah Dilaksanakan Guru Geografi SMA Terakriditasi A di Kota Singaraja untuk menghadapi Kendala-Kendala yang Dilami dalam Penerapan Asesmen Autentik Berbasis HOTS

\begin{tabular}{|c|c|c|c|c|}
\hline No & Sekolah & Solusi dan Kiat & Coding & $\begin{array}{c}\text { Line by Line } \\
\text { Coding }\end{array}$ \\
\hline 1 & Sekolah 1 & $\begin{array}{l}\text { Kendala dalam } \\
\text { penyusunan: Ketika } \\
\text { presentasi telah } \\
\text { selesai masing- } \\
\text { masing kelompok } \\
\text { diminta mengajukan } \\
\text { pertanyaan kepada } \\
\text { kelompok yang } \\
\text { presentasi. } \\
\text { Pertanyaan tidak } \\
\text { dapat sama dengan } \\
\text { kelompok lain. } \\
\text { Pertanyaan yang } \\
\text { berbobot akan keluar } \\
\text { dalam ulangan } \\
\text { harian. } \\
\text { Kendala dalam } \\
\text { penerapan: Sikap } \\
\text { dengan cara setelah } \\
\text { selesai waktu } \\
\text { menjawab } \\
\text { pertanyaan, guru } \\
\text { menunjuk secara }\end{array}$ & $\begin{array}{l}\text { 1. Pengajuan pertanyaan } \\
\text { saat presentasi } \\
\text { 2. Menguji Siswa } \\
\text { 3. Mengevaluasi sikap } \\
\text { 4. Sikap siswa } \\
\text { 5. Memvariasikan cara } \\
\text { evaluasi }\end{array}$ & $\begin{array}{l}\text { 1. Memvariasikan cara } \\
\text { evaluasi } \\
\text { 2 Bentuk soal beragam } \\
\text { 3. Refrensi } \\
\text { 4. Pengajuan pertanyaan } \\
\text { saat presentasi } \\
\text { 5. Menguji Siswa } \\
\text { 6. Mengevaluasi sikap } \\
\text { 7. Menyesuaikan } \\
\text { kompetensi siswa } \\
\text { 8. Meningkatkan Motivasi } \\
\text { Siswa } \\
\text { 9. Latihan Soal } \\
\text { 10. Mempertimbangkan } \\
\text { kemampuan siswa } \\
\text { 11. Menyesuaikan } \\
\text { karakter siswa } \\
\text { 12. Mengarahkan Siswa }\end{array}$ \\
\hline
\end{tabular}




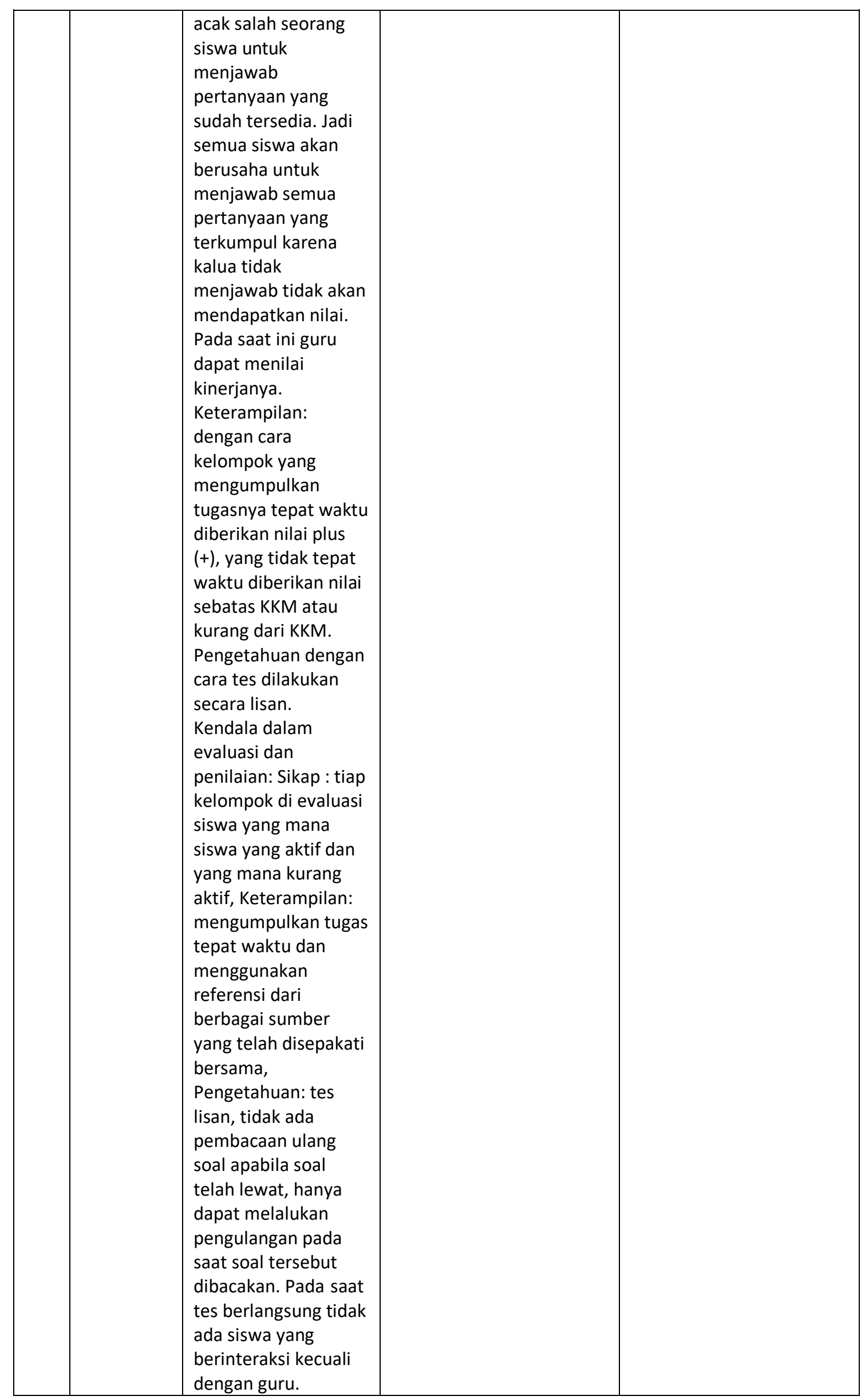




\begin{tabular}{|c|c|c|c|c|}
\hline 2 & Sekolah 2 & $\begin{array}{l}\text { Kendala saat } \\
\text { penyusunan: } \\
\text { Menyesuaikan } \\
\text { refrensi yang sesuai } \\
\text { Kendala saat } \\
\text { penerapan: } \\
\text { Mengukur dengan } \\
\text { bentuk soal beragam } \\
\text { (Objektif dan uraian). } \\
\text { Mengefektifkan } \\
\text { waktu dalam evaluasi } \\
\text { dan penilaian. }\end{array}$ & $\begin{array}{l}\text { 1. Refrensi } \\
\text { 2. Bentuk soal beragam }\end{array}$ & \\
\hline 3 & Sekolah 3 & $\begin{array}{l}\text { Kendala dalam } \\
\text { penyusunan: Analisis } \\
\text { KI dan KD harus } \\
\text { didampingi sumber } \\
\text { belajar/Refrensi, } \\
\text { menyusun IPK harus } \\
\text { menyesuaikan } \\
\text { dengan kompetensi } \\
\text { peserta didik, dan } \\
\text { Mencaari kata-kata } \\
\text { operasional yang } \\
\text { sesuai. } \\
\text { Kendala dalam } \\
\text { penerapan: } \\
\text { Meningkatkan } \\
\text { motivasi belajar } \\
\text { peserta didik, } \\
\text { mendorong peserta } \\
\text { didik untuk lebih } \\
\text { banyak literasi, dan } \\
\text { sebelumevaluasi } \\
\text { disarankan untuk } \\
\text { belajar dan berlatih. } \\
\text { 3) Kendala dalam } \\
\text { evaluasi dan } \\
\text { penilaian: Lebih } \\
\text { sering memberikan } \\
\text { latihan untuk } \\
\text { menjawab soal dan } \\
\text { menyelesaikan } \\
\text { permasalahan yang } \\
\text { dihadapi peserta } \\
\text { didik, dan } \\
\text { mendorong untuk } \\
\text { menggunakan waktu } \\
\text { belajar dan berlatih } \\
\text { lebih banyak. } \\
\text { lajala }\end{array}$ & $\begin{array}{l}\text { 1. Refrensi } \\
\text { 2. Menyesuaikan } \\
\text { kompetensi Siswa } \\
\text { 3. Meningkatkan Motivasi } \\
\text { Siswa } \\
\text { 4. Latihan Soal }\end{array}$ & \\
\hline 4 & Sekolah 4 & $\begin{array}{l}\text { Kendala dalam } \\
\text { penyusunan: } \\
\text { Mempertimbangkan } \\
\text { kemampuan siswa } \\
\text { Kendala dalam } \\
\text { penerapan: } \\
\text { Membuat soal } \\
\text { dengan kategori }\end{array}$ & $\begin{array}{l}\text { 1. Mempertimbangkan } \\
\text { kemampuan siswa } \\
\text { 2. Bentuk soal beragam } \\
\text { 3. Memvariasikan cara } \\
\text { evaluasi }\end{array}$ & \\
\hline
\end{tabular}




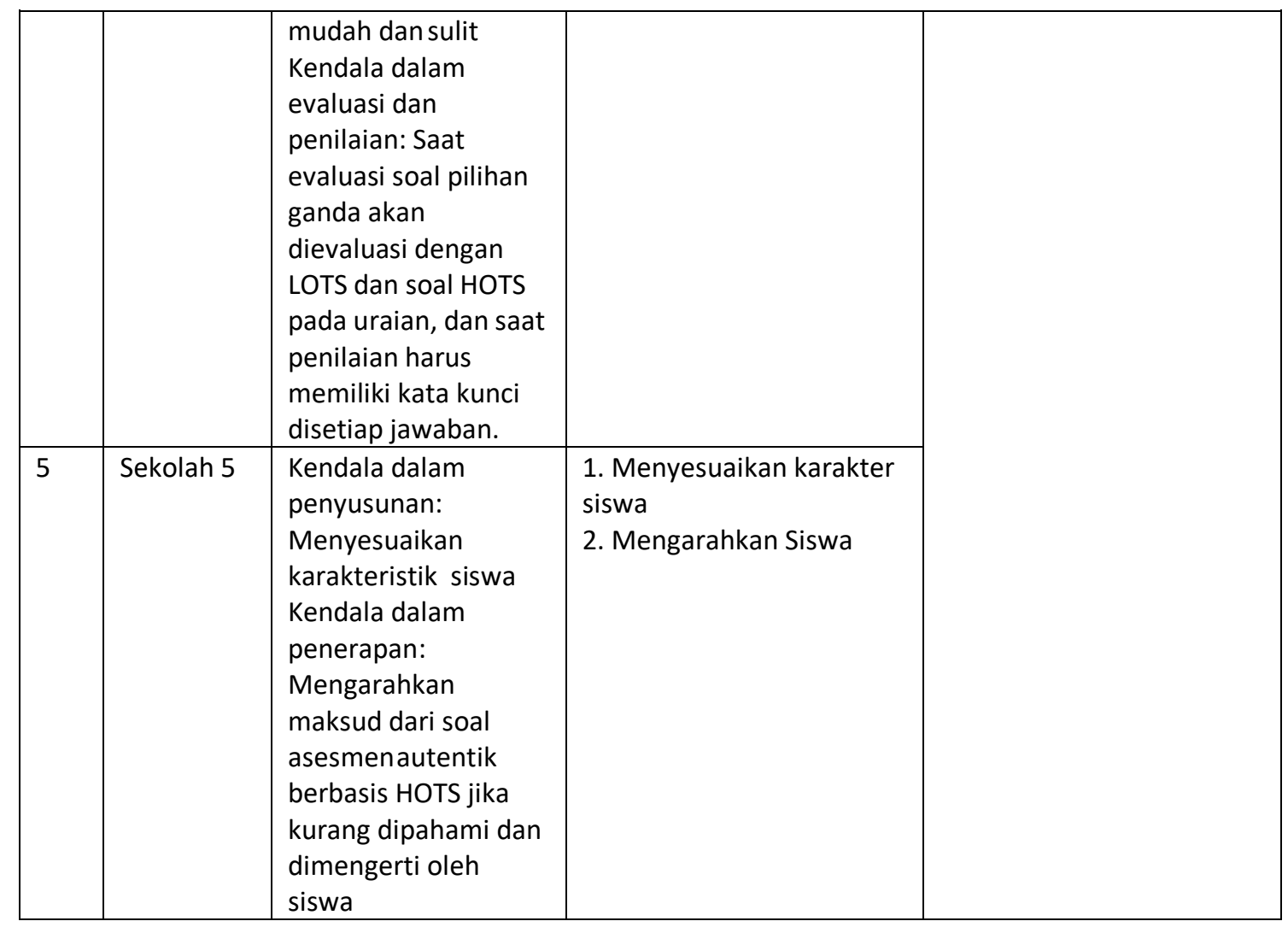

Sumber: Pengolahan data primer

Tabel 6 menunjukkan bahwa solusi yang diberikan guru sejalan dengan permasalahan yang dihadapi guru dalam menyusun soal-soal asesmen autentk berbasis HOTS. Namun demikian, solusi yang dikemukakan masih bersifat normative, sehingga dalam pengimplementasiannya perlu ditelusuri lebih lanjut.

Hasil penelitian menunjukkan bahwa secara umum pemahaman guru geografi SMA Terakriditasi A di Kota Sinagaraja terkategori sedang (nilai rata-rata 83). Hanya satu guru dari lima guru yang pemahamannya tinggi. Dengan skor 100. Namun jika dilhat antar indikator, tidak dijumapi adanya suatu pola tentang pemahaman guru geografi terhadap asesmen autentik berbasis HOTS. Hal ini menunjukkan antar guru geografi SMA Terakriditasi A di Kota Singaraja pemahamannya tidak sama yang sudah tentu sangat dipengaruhi oleh berbagai faktor. Sebagaimana yang dikemukakan oleh Anang (2019). Faktor-faktor yang mempengaruhi pemahaman guru terhadap asesmen autentik berbasis HOTS antara lain: meliputi tingkat pendidikan, latar belakang keilmuan, lama dan beban mengajar, keikutsertaan dalam pelatihan, penguasaan metode dan media, intensitas membaca, dan etos kerja guru.

Jika dilihat dari latar belakang keilmuan, semua guru berlatar belakang Pendidikan Geografi. Sementara jika memperhatikan beban mengajar, keikut sertaan dalam pelatihan, penguasaan metode dan media, intensitas membaca, dan etos kerja guru tidak jauh berbeda antara satu guru dengan guru yang lain. Pembedanya hanya pada lama mengajar dan tingkat pendidikan. Tingginya pemahaman guru geografi SMA ke-5 dibanding guru geografi SMA lainnya dapat disebabkan karena tingkat pendidikannya yang sudah S-2 sementara guru geografi SMA yang lain masih S-1.

Tidak adanya pola yang jelas jika dilihat dari indictor yang digunakan untuk mengukur pemahaman guru geografi SMA Terakriditasi A di Kota Singaraja menunjukkan bahwa masih kurangnya pemahaman mereka tentang Asesmen Autentik berbasis HOTS. Hal ini menyebabkan pemberian respon atas tes lebih banyak dilakukan dengan apa yang dipahami melalui pelatihan dan yang dibaca.

Meskipun pemahaman guru-guru geografi SMA di Kota Singaraja rata-rata terkategori sedang, namun pemahaman guru-guru tentang asesesmen autentik berbasis HOTS ini seharusnya diketahui dengan baik. Apabila guru-guru tidak mampu memahami konsep asesmen autentik berbasis HOTS maka guru-guru tidak akan menerapkan asesmen autentik berbasis HOTS dengan baik. Hal ini juga sejalan dengan penelitian Rapih \& Sutaryadi (2018) bahwa masih ditemukannya guru-guru yang belum memahami konsep dari HOTS.

Kandungan HOTS dalam Asesmen Autentik yang dikembangkan Guru SMA Terakriditasi A di Kota Singaraja masih terkategori cukup/belum sepenuhnya mengandung HOTS. Hasil penelitian menunjukan bahwa soal-soal yang telah dibuat oleh guru geografi SMA terakreditasi A dikota Singaraja belum sepenuhnya 
berbentuk HOTS. Dari kelima sekolah yang sudah diteliti, belum ada guru yang mendapatkan hasil persentase rata-rata total diatas $60 \%$. Hasil persentase rata-rata total yang diperoleh berkisaran pada $30 \%-53 \%$. Pada Hasil persentase rata-rata tiap kelasnya ada beberapa soal yang telah dibuat guru memperoleh hasil persentase ratarata $80 \%$ keatas yang berarti pada soal tersebut guru sudah menerapkan HOTS cukup banyak.

Apabila dilihat dari hasil penelitian pada pemahaman guru terhadap asesmen autentik berbasis HOTS dengan kandungan HOTS pada soal-soal yang telah dibuat oleh guru-guru tidak semua pemahaman sejalan dengan kandungan HOTS pada soal-soal yang telah dibuat. Sekolah ke-1 dan Sekolah ke-2 memiliki skor yang sama pada pemahaman asesmen autentik berbasis HOTS, yaitu 80 dengan kategori cukup paham. Kandungan HOTS pada soal-soal yang dibuat oleh guru dari kedua sekolah ini pun masih belum sepenuhnya mengandung HOTS, yaitu 38,68\% Sekolah ke-1 dan 43,27\% Sekolah ke-2, sehingga pemahaman guru cukup sejalan dengan kandungan HOTS yang terdapat pada soal yang telah dibuat. Pada Sekolah ke-3 pemahaman guru memperoleh skor 85 dengan kategori cukup paham, kandungan HOTS pada soal-soal yang telah dibuat pun belum sepenuhnya HOTS yaitu $52,96 \%$, sehingga pemahaman guru cukup sejalan dengan kandungan HOTS pada soalsoal yang telah dibuat. Meskipun skor pemahaman guru Sekolah ke-3 bukanlah skor tertinggi dari ke lima sekolah yang diteliti, namun kandungan HOTS pada soal-soal yang telah dibuat guru Sekolah ke-3 justru paling tinggi diantara kelima sekolah yang diteliti. Pada Sekolah ke-4 pemahaman guru memperoleh skor 70 dengan kategori cukup paham, kandungan HOTS pada soal-soal yang telah dibuat pun belum sepenuhnya HOTS yaitu $48,64 \%$, sehingga pemahaman guru cukup sejalan dengan kandungan HOTS pada soal-soal yang telah dibuat. Meskipun perolehan skor pemahaman guru Sekolah ke-4 terendah namun rata-rata persentase kandungan HOTS pada soal-soal yang telah dibuat bukanlah yang paling rendah, kandungan HOTS pada soal-soal yang telah dibuat oleh guru Sekolah ke-4 masih lebih tinggi dari Sekolah ke-1, Sekolah ke-2, dan Sekolah ke-5. Pada Sekolah ke-5 pemahaman guru memperolah skor 100 dengan kategori sangat paham, namun kandungan HOTS pada soal-soal yang telah dibuat oleh guru Sekolah ke-5 belum sepenuhnya mengandung HOTS yaitu $47,81 \%$. Jumlah rata-rata persentase total kandungan HOTS pada soal yang dibuat guru Sekolah ke-5 bahkan masih berada dibawah Sekolah ke-3 dan Sekolah ke-4. Pemahaman guru Sekolah ke-5 tidak sebanding dengan kandungan HOTS pada soal-soal yang telah dibuat.

Kandungan HOTS pada soal-soal yang telah dibuat oleh guru-guru masih belum sepenuhnya HOTS, hal ini sejalan dengan penelitian dari Pratama \& Istiyono (2015) bahwa penerapan HOTS pada guru-guru yang diteliti terlaksana sedang, sehingga belum sepenuhnya guru-guru menerapkan HOTS dalam pembelajaran. Hal ini juga sejalan dengan penelitian dari Rapih \& Sutaryadi (2018) bahwa guru-guru menyatakan sudah menerapkan HOTS namun kenyataam dilapamgan, tidak sepenuhnya HOTS diterapkan dalam seluruh proses pembelajaran.

Kandungan HOTS pada soal yang telah dibuat guru-guru belum sepenuhnya HOTS dapat dikarenakan oleh pemahaman guru-guru yang masih kurang mengenai HOTS mulai dari pemahaman konsep, ciri-ciri, langkah penyusunan, dan cara mengevaluasi. Selain itu soal-soal yang dibuat oleh guru-guru belum sepenuhnya HOTS dapat disebabkan oleh kesulitan-kesulitan yang dialami oleh guru-guru. Pada pemaparan kendalakendala penerapan HOTS, guru-guru banyak menyatakan kesulitan dalam penyusunan soal disebabkan oleh kesulitan dalam pemilihan KI dan KD, refrensi yang masih kurang, dan waktu yang dibutuhkan dalam penyusunan soal-soal berbasis HOTS cukup lama sehingga guru-guru merasa kekurangan waktu untuk penyusunan soal.

Penerapan asesmen autentik berbasis HOTS yang dilaksanakan oleh guru-guru geografi SMA ini diakui memang mengalami beberapa kendala dalam penerapannya. Hal ini sejalan dengan penelitian Hidayati (2017) bahwa guru-guru masih mengalami kesulitan dalam penyusunan evaluasi dalam bentuk HOTS. Hal ini juga sejalan dengan penelitian Rapih \& Sutaryadi (2018) bahwa guru-guru menyatakan kesulitan dan memiliki kendala dalam penerapan HOTS. Adanya kendala menjadikan proses penerapan asesmen autentik berbasis HOTS cukup sulit karena kendala-kendala yang ada. Meskipun demikian, guru-guru sudah pernah mencoba dan melaksanakan beberapa solusi atau kiat-kiat untuk mensiasati atau menghadapi kendala tesebut. Solusi-solusi tersebut dinilai cukup efektif bagi guru-guru dalam menghadapi kendala yang ada.

Setiap guru pada kelima SMA yang terakreditasi A dikota Singaraja mengalami sebagian besar kendala yang berbeda dengan solusi yang berbeda pula. Mulai dari kendala saat penyusunan asesmen autentik berbasis HOTS, saat penerapan asesmen autentik berbasis HOTS, dan pada saat penilaian/evaluasi asesmen autentik berbasis HOTS. Kendala-kendala dalam setiap tahap tersebut berbeda dengan solusi yang dilaksanakan berbeda pula. Rata- rata guru menyatakan bahwa mereka mengalami kesulitan dalam penyusunan asesmen autentik berbasis HOTS hal ini sejalan dengan kandungan HOTS dalam soal-soal yang sudah mereka buat yang rata-rata masih terkategori belum memenuhi standar HOTS sepenuhnya.

Kendala-kendala yang dihadapi oleh guru-guru SMA terakreditasi A dikota Singaraja pada saat penyusunan cukup bervariasi. Guru-guru cenderung terkendala dalam pemilihan KD, penyusunan indikator, pemilihan soal, dan juga saat penyusunan soal. Pada evaluasi pemahaman guru, guru-guru rata-rata menjawab 
dengan benar langkah- langkah penyusunan asesmen autentik bebrbais HOTS, sehingga guru dianggap sudah cukup paham. Jika dikaitkan lebih lanjut kendala yang dihadapi saat penyusunan dengan pemahaman guru mengenai penyusunan asesmen autentik berbasis HOTS guru-guru tidak begitu mengalami kendala yang berat dan masih dapat diatasi dengan baik. Penyelesaian kendala ini berhubungan dengan pemahaman guru yang dianggap cukup paham. Kendala- kendala yang dihadapi oleh guru-guru SMA terakreditasi A dikota Singaraja pada saat penerapan cukup bervariasi. Dalam penerapan asesmen autentik berbais HOTS, guru-guru cenderung terkendala pada siswa. Kendala tersebut antara lain: pemahaman siswa yang kurang, level kognitif siswa yang berbeda-beda, kurangnya respon peserta didik, peserta didik kurang menjawab dengan maksimal, dan siswa yang minim refrensi. hal ini sejalan dengan penelitian Putri \& Sofyan (2019) bahwa peserta didik sangat erpengaruh pada kendala yang dihadapi. Kendala-kendala yang dihadapi oleh guru-guru SMA terakreditasi $A$ dikota Singaraja pada saat evaluasi bervariasi namun cendurung terkendala pada masalah waktu, hal ini sejalan dengan penelitian Putri \& Sofyan (2019) bahwa kendala yang dihadapi guru adalah alokasi waktu sedangkan pembelajaran berbabis HOTS ini siswa dituntut beerpikir tinggi dan memerlukan waktu yang cukup panjang. Jika dikaitkan dengan evaluasi pemahaman guru, guru-guru belum menjawab benar dengan sepenuhnya mengenai cara menilai siswa dengan asesmen autentik berbasis HOTS, sehingga dapat dilihat bahwa guru yang mengalami kendala terutama pada waktu belum memahami sepenuhnya bagaimana seharusnya melakukan penilaian agar tidak mengalami kendala yang cukup banyak dan dapat dilaksanakan solusi yang lebih sesuai.

Perbedaan kendala yang dihadapi oleh masing-masing guru ini dapat disebabkan oleh pengalaman guru yang berbeda-beda. Hal ini diungkapkan pada penelitian Ayuni (2015), selain pengalaman ada beberapa hal yang juga dapat mempengaruhi perbedaan kendala yang dialami yaitu: pemahaman HOTS yang berbeda-beda, perbedaan banyaknya referensi yang dipahami dan dimiliki oleh masing-masing guru, dan karakteristik siswa yang berbeda pada setiap sekolah.

\section{Simpulan dan saran}

Berdasarkan hasil penelitian dan pembahasan yang telah diuraikan, dapat disimpulkan beberapa hal sebagai berikut. (1) Pemahaman guru SMA terakreditasi A di kota Singaraja terhadap asesmen autentik berbasis HOTS rata- rata terkategori cukup paham dengan rentang skor 70-85, namun jika dilihat antar sekolah terdapat variasi. Skor tertinggi dicapai oleh Guru Sekolah ke-5 (100), sedangkan yang terendah dicapai oleh Guru SMAN 4 Singaraja (70). Variasi pemahaman guru terhadap Asesmen autentik berbasis HOTS yang terdapat antar sekolah tersebut tidak konsisten dengan kandungan HOTS soal-soal yang dikembangkan. (2) Kandungan HOTS dalam asesmen autentik yang dikembangkan guru-guru geografi SMA terakreditasi A di kota Singaraja terkategori sedang (belum sepenuhnya mengandung HOTS). Hal tersebut terlihat secara konsisten antar sekolah, antar aspek, maupun antar jenjang kelas. Guru yang pemahaman Asesmen Autentik berbasis HOTS-nya tinggi belum tentu mampu mengembangkan soal-soal berbasis HOTS. (3) Kendala-kendala yang dihadapi oleh setiap guru geografi SMA terakreditasi A di kota Singaraja cukup beragam. Namun demikian kendala-kendala yang utama dihadapi oleh guru terletak pada kekurangan alokasi waktu dan kendala pada peserta didik. Kendala tersebut akan mengakibatkan guru cukup terhambat dalam penerapan asesmen autentik berbasis HOTS

Saran yang dapat disampaikan berdasarkan penelitian yang telah dilakukan, sebagai berikut. (1) Bagi guru, diharapkan agar lebih memahami kembali asesmen autentik berbasis HOTS yang telah ditetapkan standar oleh pemerintah, sehingga pada saat pengimplementasian asesmen autentik berbasis HOTS guru sudah paham betul bagaimana seharusnya soal-soal HOTS yang dibuat. Guru juga perlu lebih banyak lagi mencari referensi mengenai contoh-contoh soal yang sudah dapat dikategorikan HOTS agar guru memiliki acuan dalam membuat soal-soal berbasis HOTS. (2) Bagi kepala sekolah diharapkan memberikan kesempatan kepada guru untuk lebih banyak mengikuti kegiatan akademik berupa pelatihan yang berkaitan dengan pemahaman dan pelatihan penyusunan asesmen autentik berbasis HOTS, sehingga guru-guru mendapatkan pengalaman yang lebih nyata dilapangan.

\section{UCAPAN TERIMAKASIH}

Penulis mengucapkan terimakasih kepada seluruh Kepala Sekolah dan Guru Geografi SMA Negeri 1 Singaraja, SMA Negeri 3, SMA Negeri 3 Singaraja, SMA Negeri 4 Singaraja, dan SMA Laboratorium Undiksha Singaraja yang telah memberikan ijin untuk melaksanakan penelitian dan banyak memberikan informasi terkait penelitian ini. Dr. Ida Bagus Made Astawa, M.Si. selaku Pembimbing I yang telah banyak memberikan bimbingan, arahan, saran dan motivasi selama proses penulisan artikel ini. 


\section{Daftar Rujukan}

Abdullah, A. H., Mokhtar, M., Halim, N. D. A., Ali, D. F., Tahir, L. M., \& Kohar, U. H. A. (2017). Mathematic Teachers level of Knowledge and Practice on the Implementation of Higher-Order Thinking Skills(HOTS). EURASIA Journal of Mathematics Science and Technology Education, 13(1), 3-17.

Anggito, A., \& Setiawan, J. (2018). Metodelogi Penelitian Kualitatif (E. D. Lestari (Ed.)). CV Jejak. https://books.google.co.id/books?id=59V8DwAAQBAJ\&printsec=frontcover\&dq=pengertian+penelitian+ deskriptif+kualitatif\&hl=id\&sa=X\&ved=0ahUKEwjbjsa5r9vqAhX863MBHdtrBQ8Q6AEICDAA\#v=onepage\& $q=$ pengertian penelitian deskriptif kualitatif\& $f=f a l s e$

Astawa, I. B. M. (2015). Reformasi Pendidikan Di Era Otonomi Daerah Memasuki Era Global. Media Komunikasi Geografi, 16(2), 1-17.

Ayuni, F. N. (2015). Pemahaman Guru Terhadap Pendekatan Saintifik (Scientific Approach) Dalam Pembelajaran Geografi. Jurnal Pendidikan Geografi, 15(2), 1-7.

Fanani, M. Z. (2018). Strategi Pengembangan Soal Higher Order Thinking Skill(HOTS) dalam Kurikulum 2013. Edudeena, II(1), 57-76.

Helaluddin, \& Wijaya, H. (2019). Analisis Data Kualitatif: Sebuah Tinjauan Teori \& Praktik. Sekolah Tinggi Theologia Jaffray.

Hidayati, A. U. (2017). Melatih Keterampilan Berpikir Tingkat Tinggi Dalam Pembelajaran Matematika Pada Siswa Sekolah Dasar. TERAMPIL, 4(2), 143-156.

Iskandar, D., \& Senam. (2015). Studi Kemampuan Guru Kimia SMA Lulusan UNY Dalam Mengembangkan Soal UAS berbasis HOTS. Jurnal Inovasi Pendidikan IPA, 1(1), 65-72.

Koswara, D. (2014). Siswa Harus Berpikir "Hots." Kompasiana.

Marhaeni, A. A. I. N., \& Kusuma, I. P. I. (2017). Analisis Implementasi Asesmen Autentik pada Pembelajaran Bahasa Inggris dalam Implementasi Kurikulum 2013 di SMA di Bali. Seminar Nasional Riset Inovatif 2017, 555-561.

Nurhayani. (2017). Kesulitan Guru Dalam Pengembangan Keterampilan Berpikir Tingkat Tinggi Siswa Pada Pembelajaran Biologi Kelas XII Di SMA Negeri 2 Gowa. Universitas Islam Negeri Alauddin Makassar.

Peraturan Menteri Pendidikan dan Kebudayaan Republik Indonesia Nomor 36 Tahun 2018 Tentang Perubahan Aatas Peraturan Menteri Pendidikan dan Kebudayaan Nomor 59 Tahun 2014 Tentang Kurikulum 2013 Sekolah Menengah Atas/Madrasah Aliyah. (2018).

Pratama, N. S., \& Istiyono, E. (2015). Studi Pelaksanaan Pembelajaran Fisika Berbasis Higher Order Thinking (Hots) Pada Kelas X Di SMA Negeri Kota Yogyakarta. Prosiding Seminar Nasional Fisika Dan Pendidikan Fisika (SNFPF) Ke-6, 104-112.

Putri, B. A., \& Sofyan, F. A. (2019). Analisis Kesulitan Proses Pembelajaran Berbasis Hots di Kelas VSDN 4 Muara Padang. El-Ibtidaiy: Journal of Primary Education, 2(2), 59-73.

Rapih, S., \& Sutaryadi. (2018). Perpektif guru sekolah dasar terhadap Higher Order Tinking Skills (HOTS): pemahaman, penerapan dan hambatan. Premiere Educandum, 8(1), 78-87.

Shidiq, A. S., Masykuri, M., \& Susanti, E. (2015). Analisis Higher Order Thinking Skills(HOTS) Menggunakan Instrumen Two-Tier Multiple Choice Pada Materi Kelarutan dan Hasil Kali Kelarutan Untuk Siswa Kelas XI SMAN 1 Surakarta. Prosiding Seminar Nasional Pendidikan Sains, 159-166.

Undang Undang Nomor 20 Tahun 2003 Tentang Sistem Pendidikan Nasional. (2003).

Wahyuningtyas, N., \& Ratnawati, N. (2018). Workshop Pengembangan Soal Higher Order Thinking Skill (HOTS) Bagi Guru-guru MGMP IPS Kabupaten Malang Pelatihan Penyusunan. Jurnal Praksis Dan Dedikasi Sosial, 1(2), 73-79.

Zebua, D. R. Y., \& Harmalis. (2019). Analisis High Order Thinking Skill (Hots) Pada Tujuan Dan Asesmen Mata Pelajaran Kimia. Journal On Education, 01(04), 774-782. 